\title{
Inhibition of neutrophil function following exposure to the Aspergillus fumigatus toxin fumagillin
}

\author{
Correspondence \\ Kevin Kavanagh \\ kevin.kavanagh@nuim.ie
}

Received 10 December 2009

Accepted 3 March 2010
John P. Fallon, ${ }^{1}$ Emer P. Reeves ${ }^{2}$ and Kevin Kavanagh ${ }^{1}$

\author{
${ }^{1}$ Medical Mycology Unit, Department of Biology, National Institute for Cellular Biotechnology, \\ National University of Ireland Maynooth, Co. Kildare, Ireland \\ ${ }^{2}$ Respiratory Research Division, Department of Medicine, Royal College of Surgeons in Ireland, \\ Beaumont Hospital, Dublin 9, Ireland
}

The filamentous fungus Aspergillus fumigatus produces a variety of enzymes and toxins that may facilitate fungal colonization of tissue and evasion of the host immune response. One such toxin, fumagillin, was investigated for its ability to inhibit the action of neutrophils, which are a central component of the innate immune response to microbial infection. Neutrophils exposed to $2 \mu \mathrm{g}$ fumagillin $\mathrm{ml}^{-1}$ for 25 min showed a significantly reduced ability to kill yeast cells $(P<0.02)$, to phagocytose conidia of $A$. fumigatus $(P<0.023)$ and to consume oxygen $(P<0.032)$. The ability of neutrophils to generate superoxide is dependent upon the action of a functional NADPH oxidase complex which is composed of cytosolic ( $p 40^{\text {phox }}, p 47^{\text {phox }}, p 67^{\text {phox }}$, Rac2) and membrane (gp91 ${ }^{\text {phox }}$ ) proteins. Exposure of neutrophils to fumagillin inhibited the formation of the NADPH oxidase complex by blocking the translocation of $\mathrm{p} 47^{\text {phox }}$ from the cytosolic to the membrane fraction $(P=0.02)$. In addition to the production of superoxide, neutrophils also undergo degranulation, which leads to the release of proteolytic enzymes that contribute to the microbicidal activity of the cell. Fumagillin-treated neutrophils showed reduced degranulation as evidenced by lower myeloperoxidase activity $(P<0.019)$. Fumagillin-treated cells demonstrated reduced levels of F-actin, thus indicating that retarding the formation of F-actin may contribute to the inhibition of the structural rearrangements required in the activated neutrophil. This work indicates that fumagillin may contribute to reducing the local immune response by altering the activity of neutrophils and thus facilitate the continued persistence and growth of $A$. fumigatus in the host.

\section{INTRODUCTION}

The filamentous fungus Aspergillus fumigatus is a significant cause of disease in immunocompromised patients and is responsible for up to $4 \%$ of deaths in tertiary hospitals in Europe (Brookman \& Denning, 2000). A variety of toxins and enzymes produced by $A$. fumigatus may facilitate growth within the host and impair the host's immune response (Tekaia \& Latgé, 2005). One of the most widely studied toxins, gliotoxin, can retard the ciliary beat frequency within the lung (Amitani et al., 1995), induce apoptosis in cells of the immune system (Sutton et al., 1994; Orciuolo et al., 2007), exacerbate invasive aspergillosis (Sutton et al., 1996) and disrupt the formation of a functional NADPH oxidase complex in neutrophils (Tsunawaki et al., 2004).

The toxin fumagillin $\left(\mathrm{C}_{26} \mathrm{H}_{34} \mathrm{O}_{7} ; 458.6 \mathrm{Da}\right)$ is also produced by A. fumigatus upon hyphal development (Mitchell et al., 1997). Early work characterized the amoebicidal

Abbreviations: MPO, myeloperoxidase; PMA, phorbol 12-myristate 13-acetate. properties of this compound (McCowen et al., 1951) and recently fumagillin has been identified as an inhibitor of angiogenesis through the covalent interaction of methionine aminopeptidase-2 (MetAP-2), a feature which is shared with its drug target analogue TNP-470 (Ingber et al., 1990). Fumagillin can retard the ciliary beat frequency of pulmonary epithelial cells; however, its effect is not as significant as that induced by gliotoxin (Amitani et al., 1995).

Fumagillin has undergone clinical trials as an oral treatment for intestinal microsporidiasis in patients with HIV infection but adverse effects such as thrombocytopenia, neutropenia, hyperlipasaemia and abdominal cramps were recorded (Molina et al., 2000). Successful therapeutic use of fumagillin has been reported when applied topically in cases of microsporidial keratoconjunctivitis in humans (Diesenhouse et al., 1993). The fumagillin dicyclohexamine salt was found to induce sister chromatid exchanges at doses as low as $0.34 \mu \mathrm{g} \mathrm{ml}{ }^{-1}$ in human peripheral blood lymphocytes (Stevanovic et al., 2008). 
Neutrophils provide the first line of defence of the innate immune system by phagocytosing, killing and digesting bacteria and fungi (Bellocchio et al., 2004). Degradation of the ingested microbe occurs in the phagocytic vacuole by a combination of oxidative and non-oxidative mechanisms. Oxidative mechanisms refer to microbial killing that is dependent upon the production of reactive oxygen species, triggered by activation of the NADPH oxidase (Curnutte et al., 1987), which causes the single electron reduction of oxygen to superoxide anion $\left(\mathrm{O}_{2}^{--}\right)$(Babior et al., 1973). The active oxidase is a multicomponent system involving flavocytochrome $b_{558}$. A number of cytosolic proteins are also required to activate the flavocytochrome $b$, including $\mathrm{p} 67^{\text {phox }}, \mathrm{p} 47^{\text {phox }}$ and the small GTP-binding protein Rac in the GTP-bound form (Standish \& Weiser, 2009; Wallach \& Segal, 1996). These cytosolic components, together with amphiphiles such as sodium dodecyl sulphate and membrane fractions, or pure flavocytochrome, induce electron transport in vitro in what is known as the cell-free system (Curnutte et al., 1987; de Mendez \& Leto, 1995). Translocation of the cytosolic components of the NADPH oxidase (p40 $0^{\text {phox }}, \mathrm{p} 67^{\text {phox }}$, $\mathrm{p} 47^{\mathrm{phox}}$ and Rac) to the membrane component is required to produce a functional complex capable of producing superoxide (Sumimoto et al., 1996; Tsunawaki et al., 2004; Wientjes et al., 1993). The syndrome of chronic granulomatous disease (CGD) provides the most definitive evidence for the clinical importance of the NADPH oxidase as CGD is characterized by predisposition to bacterial and fungal infection and an absence of NADPH oxidase activity (Thrasher et al., 1994).

The antimicrobial systems of neutrophils which can operate in the absence of oxygen are due to neutral serine proteases, hydrolytic enzymes and cationic proteins. These proteolytic enzymes are packaged within cytoplasmic granules that are released upon cell activation (Spitznagel, 1990). Myeloperoxidase (MPO) is a component of primary granules and in the presence of hydrogen peroxide produces hypochlorous acid. Defects associated with neutrophil granules include the inherited granule deficiency Chédiak-Higashi syndrome, which is a rare autosomal recessive disorder associated with a prominent defect in formation of neutrophil granules resulting in increased susceptibility to infection (Malech \& Nauseef, 1997).

It has been established that gliotoxin inhibits the action of neutrophils by blocking the translocation of $\mathrm{p} 47^{\text {phox }}$ and p $67^{\text {phox }}$ from the cytosolic fraction to the membrane fraction (Tsunawaki et al., 2004). The aim of the work presented here was to establish the effect of fumagillin on human neutrophils since its production in the body by $A$. fumigatus could retard this element of the immune response and facilitate the growth and persistence of the fungus. Furthermore, the inhibition of neutrophil function mediated by fungal toxins could be responsible for enhanced bacterial and/or fungal colonization and disruption of the host immune response.

\section{METHODS}

Chemicals. All chemicals and reagents were of the highest purity and were purchased from Sigma Aldrich unless stated otherwise. Fumagillin $\left(1 \mathrm{mg} \mathrm{ml}^{-1}\right)$ was prepared in a sterile environment by dissolving in HPLC-grade methanol and serially diluting in PBS to $2 \mu \mathrm{g} \mathrm{ml}^{-1}$.

Fungal strains. Candida albicans, isolate MEN, was cultured in YEPD broth $[2 \%(\mathrm{w} / \mathrm{v})$ glucose, $2 \%(\mathrm{w} / \mathrm{v})$ bactopeptone (Difco Laboratories), $1 \%(\mathrm{w} / \mathrm{v})$ yeast extract (Oxoid)] at $30{ }^{\circ} \mathrm{C}$ and 200 r.p.m. in an orbital incubator. Stocks were maintained on YEPD agar plates (as above but supplemented with $2 \%, w / v$, agar). $A$. fumigatus ATCC 26933 was obtained from the American Type Culture Collection and was grown on malt extract agar (Difco Laboratories).

Isolation of conidia. A. fumigatus conidia were isolated by washing plates in PBS containing $0.1 \%$ Tween 80 . Following centrifugation at $5000 \mathrm{~g}$ for $10 \mathrm{~min}$, the conidial pellet was washed three times in PBS to remove excess Tween. Conidial number was ascertained by haemocytometry.

Preparation of human neutrophils. Human neutrophils were isolated from healthy volunteers (ethical permission granted by NUI Maynooth Ethics Committee), and separated from blood collected in $10 \mathrm{ml}$ heparinized tubes (BD Vacutainer Systems) under vacuum by dextran sedimentation and Ficoll-Hypaque (Axis-Shield PoC AS) centrifugation as previously described (Reeves et al., 2002). Erythrocytes were removed by hypotonic lysis in water and brought back to osmolarity using a $1.8 \%(\mathrm{w} / \mathrm{v}) \mathrm{NaCl}$ solution. The cells were resuspended in PBS ( $\mathrm{pH}$ 7.4) containing $5 \mathrm{mM}$ glucose and used immediately. Viability was assessed using the trypan blue exclusion assay (Eichner et al., 1986).

In vitro phagocytosis and killing of pathogenic targets by human neutrophils. Neutrophils $\left(1 \times 10^{7} \mathrm{ml}^{-1}\right)$ were incubated in the presence of $2 \mu \mathrm{g}$ fumagillin $\mathrm{ml}^{-1}$ for $25 \mathrm{~min}$ at $37^{\circ} \mathrm{C}$. A. fumigatus conidia were opsonized using human serum for $45 \mathrm{~min}$ at $37^{\circ} \mathrm{C}$. Phagocytosis was measured by incubating pre-treated neutrophils $\left(1 \times 10^{7}\right)$ with opsonized A. fumigatus conidia $\left(2 \times 10^{7}\right)$ in a stirred thermally controlled chamber at $37{ }^{\circ} \mathrm{C}$ in a final volume of $1 \mathrm{ml}$. An aliquot was removed immediately after the addition of conidia to the cells $(t=0)$, and after a further 30, 60 and $120 \mathrm{~min}$ of incubation. The viability of neutrophils before $(98.1 \pm 2.2 \%)$ and after $(94.5 \pm 1.5 \%)$ the phagocytosis assay did not change significantly $(P=0.6)$. Three hundred neutrophils were counted and the number of cells containing phagocytosed conidia was ascertained microscopically. The mean number \pm standard error was calculated.

Assays to determine the effect of $2 \mu \mathrm{g}$ fumagillin $\mathrm{ml}^{-1}$ on the microbicidal activity of neutrophils $\left(1 \times 10^{7}\right)$ employed serumopsonized C. albicans at a target ratio of $5 \times 10^{6}$ to $1 \times 10^{7}$ neutrophils in a final volume of $1 \mathrm{ml}$. An aliquot was removed at 0, 20, 40 and $60 \mathrm{~min}$, serially diluted in ice-cold minimal essential medium (Sigma Aldrich) to quench phagocytosis and plated on YEPD plates to ascertain viability. The percentage reduction in viability of $C$. albicans was calculated based upon the viability of yeast cells at $t=0$ (Reeves et al., 2002).

Determination of oxygen consumption. Oxygen consumption was measured in a temperature-controlled $\left(37^{\circ} \mathrm{C}\right)$ chamber that was attached to a Clark-type oxygen electrode based on the fact that the oxygen content of PBS at $37^{\circ} \mathrm{C}$ is $230 \mathrm{nmol} \mathrm{ml}^{-1}$ (Segal \& Coade, 1978). Neutrophils $\left(1 \times 10^{7}\right)$ were pre-treated with $2 \mu \mathrm{g}$ fumagillin $\mathrm{ml}^{-1}$ for $25 \mathrm{~min}$ at $37^{\circ} \mathrm{C}$ and $1 \times 10^{7}$ cells were placed in the 
thermally controlled stirred chamber and stimulated with $1 \mu \mathrm{g}$ phorbol 12-myristate 13-acetate (PMA) $\mathrm{ml}^{-1}$.

Subcellular fractionation of neutrophils. Neutrophils $\left(1 \times 10^{8}\right.$ $\left.\mathrm{ml}^{-1}\right)$ were stimulated with PMA $\left(1 \mu \mathrm{g} \mathrm{ml}^{-1}\right)$ in the presence of $2 \mu \mathrm{g}$ fumagillin $\mathrm{ml}^{-1}$. Following treatment, cells were pelleted by centrifugation and resuspended in $200 \mu \mathrm{l}$ Breaks buffer $[10 \mathrm{mM}$ $\mathrm{KCl}, 3 \mathrm{mM} \mathrm{NaCl}, 4 \mathrm{mM} \mathrm{MgCl}_{2}, 10 \mathrm{mM}$ piperazine- $N, N^{\prime}$-bis(2ethanesulfonic acid); $\mathrm{pH}$ 7.2] (Reeves et al., 2002) containing protease inhibitors $\left(10 \mu \mathrm{g} \mathrm{ml}^{-1}\right.$ leupeptin, pepstatin A, aprotinin and $N \alpha-p$ tosyl-L-lysine chloromethyl ketone hydrochloride), sonicated (Bandelin Sonopuls; Bandelin Electronics) three times for $5 \mathrm{~s}$ at $20 \%$ power, and centrifuged at $200 \mathrm{~g}$ for $10 \mathrm{~min}$ at $4{ }^{\circ} \mathrm{C}$. The postnuclear supernatant was centrifuged at $100000 \mathrm{~g}$ for $1 \mathrm{~h}$ at $4{ }^{\circ} \mathrm{C}$ in a Beckman SW60 TI rotor. Following centrifugation, the membrane pellet was solubilized in $2 \%$ Triton X-100, $150 \mathrm{mM} \mathrm{NaCl}, 1 \%(\mathrm{w} / \mathrm{v})$ sodium deoxycholate for $1 \mathrm{~h}$ at $4{ }^{\circ} \mathrm{C}$. The solubilized fraction was centrifuged at $7000 \mathrm{~g}$ to remove any membrane debris (Renwick et al., 2007). Bradford Protein Assay reagent (Bio-Rad Laboratories) was used to assay the amount of protein in each fraction, using BSA as a standard.

Degranulation of neutrophils. Neutrophils $\left(5 \times 10^{7} \mathrm{ml}^{-1}\right)$ were pre-treated for $25 \mathrm{~min}$ in the presence of $2 \mu \mathrm{g}$ fumagillin $\mathrm{ml}^{-1}$ at $37^{\circ} \mathrm{C}$ and resuspended in PBS containing $5 \mathrm{mM}$ glucose and protease inhibitors as described above. Following PMA $\left(1 \mu \mathrm{g} \mathrm{ml}^{-1}\right)$ stimulation in a stirred chamber, an aliquot was removed at $0,3,6$ and $9 \mathrm{~min}$. Cells were removed by centrifugation $(800 \mathrm{~g})$. The protein content of the supernatant was precipitated and prepared for electrophoresis and immunoblotting.

MPO activity assay. Quantification of MPO activity was ascertained using a standard activity assay (Invitrogen EnzChek) and used according to the manufacturer's specifications. Briefly, $50 \mu \mathrm{l}$ cell-free supernatant $(10 \mu \mathrm{g}$ protein) was assessed for peroxidation activity by addition to $100 \mu \mathrm{l} 2 \times$ Amplex UltraRed reagent. The non-fluorescent substrate is oxidized by $\mathrm{H}_{2} \mathrm{O}_{2}$ redox intermediates of MPO to form a fluorescent product. Fluorescence intensity was read at excitation $530 \mathrm{~nm}$ and emission at $590 \mathrm{~nm}$. Fluorescence was recorded using a Synergy HT microplate reader (BioTek).

Quantification of F-actin assembly. Neutrophils $\left(5 \times 10^{7}\right)$ were incubated in the presence or absence of fumagillin at $37{ }^{\circ} \mathrm{C}$ as described above. Following PMA stimulation $\left(1 \mu \mathrm{g} \mathrm{ml}{ }^{-1}\right)$, neutrophils were pelleted, resuspended in Breaks buffer and lysed by sonication. Following centrifugation at $200 \mathrm{~g}$ for $10 \mathrm{~min}$ at $4{ }^{\circ} \mathrm{C}$, the supernatant was removed and prepared for electrophoresis and immunoblotting with anti-F-actin polyclonal antibody.

Electrophoresis and immunoblotting. Samples were separated by SDS-PAGE $(12.5 \%, w / v$, acrylamide), and protein profiles were visualized by colloidal Coomassie staining. For Western blotting, the protein was transferred to a nitrocellulose membrane using a wet blotter at $100 \mathrm{~V}$ for $70 \mathrm{~min}$. Rabbit polyclonal antisera raised against human $\mathrm{p} 47^{\text {phox }}$ were used at a dilution of $1 / 2000$ for $1 \mathrm{~h}$. MPO antiserum raised in rabbit (Genway) was used at a dilution of 1/650 overnight at $4{ }^{\circ} \mathrm{C}$. F-actin antisera raised in mouse (Millipore) were used at a dilution of $1 / 3000$ overnight at $4{ }^{\circ} \mathrm{C}$. Secondary antibody employed horseradish peroxidase-linked rabbit antisera at a dilution of $1 / 2000$, or horseradish peroxidase-linked mouse antisera at a dilution of 1/2500. Enhanced chemiluminescence (Pierce Biotechnology) was employed to develop reactive protein bands and immuno-bands were quantified by densitometry using ImageQuant software.

Immunofluorescence. Immunofluorescence microscopy was performed as described previously (Renwick et al., 2007). Cells were fixed with $4 \%(\mathrm{v} / \mathrm{v})$ paraformaldehyde, permeabilized with $0.2 \%(\mathrm{v} / \mathrm{v})$ Triton X-100 and blocked with $10 \mathrm{mM} \mathrm{NaBH}_{4}$. The cells were incubated with primary antibody against $\mathrm{p} 47^{\text {phox }}$ or against MPO (Genway) overnight at $4{ }^{\circ} \mathrm{C}$. The slides were washed in PBS and incubated with tetramethylrhodamine isothiocyanate goat anti-rabbit IgG secondary antibody (The Jackson Laboratory) for $1 \mathrm{~h}$. The controls for this experiment included cells alone and cells exposed to secondary antibody. For rhodamine-coupled phalloidin staining, neutrophils were fixed and permeabilized as described previously and incubated with $0.8 \mu \mathrm{M}$ rhodamine-coupled phalloidin overnight at $4{ }^{\circ} \mathrm{C}$. The slides were washed three times in PBS and viewed with an Olympus FluoView 1000 confocal microscope.

Statistics. All values are the mean of at least three independent determinations \pm SD. Experimental data were tested for statistical significance at $P<0.05$ using a Students $t$-test (Minitab 14 package).

\section{RESULTS}

\section{Fumagillin inhibits phagocytosis and killing by purified neutrophils}

Previous work that examined the interaction of fumagillin with human neutrophils employed concentrations of up to $128 \mu \mathrm{g}$ fumagillin $\mathrm{ml}^{-1}$ and an exposure time of $7 \mathrm{~min}$ (Tsunawaki et al., 2004). In this work, we employed a fumagillin concentration which did not affect neutrophil viability. Neutrophils were incubated in the presence of 1 or $2 \mu \mathrm{g}$ fumagillin $\mathrm{ml}^{-1}$ for $25 \mathrm{~min}$ prior to mixing with opsonized C. albicans cells in a ratio of $2: 1$ neutrophils to yeast at $37{ }^{\circ} \mathrm{C}$. Aliquots of cells were removed, serially diluted in ice-cold minimal essential medium and plated onto YEPD agar plates in order to establish the viability of yeast cells in the chamber. The results indicate (Fig. 1) that neutrophils pre-incubated in the presence of methanol killed $94.71 \pm 4.32 \%$ of C. albicans cells in $60 \mathrm{~min}$. Neutrophils that had been pre-exposed to $1 \mu \mathrm{g}$ fumagillin $\mathrm{ml}^{-1}$ showed no significant difference in the rate of killing compared to solvent-treated neutrophils $(P=0.6)$. In contrast, those cells that had been exposed to $2 \mu \mathrm{g}$ fumagillin $\mathrm{ml}^{-1}$ showed a rate of killing similar to that of the control up to $20 \mathrm{~min}(P=0.247)$ but thereafter the rate of killing was greatly reduced. At $60 \mathrm{~min}, 58.1 \pm 7.4 \%$ of $C$. albicans cells had been killed, which was significantly less than that achieved by the control cells at $P<0.02$.

Based on the above results, $2 \mu \mathrm{g}$ fumagillin $\mathrm{ml}^{-1}$ was chosen for subsequent analysis as being the lowest concentration capable of eliciting a response. To investigate the effect of fumagillin on the process of neutrophil phagocytosis, cells were exposed to $2 \mu \mathrm{g}$ fumagillin $\mathrm{ml}^{-1}$ for $25 \mathrm{~min}$ at $37^{\circ} \mathrm{C}$ prior to incubation with serumopsonized A. fumigatus conidia at a ratio of $1: 2$ neutrophils to conidia. Samples were removed periodically and the number of conidia internalized in neutrophils was assessed microscopically. The results (Fig. 2) demonstrate that phagocytosis was significantly reduced in neutrophils that had been exposed to fumagillin compared to the untreated or methanol-treated cells. At $120 \mathrm{~min}, 32.86 \pm$ $1.1 \%$ of fumagillin-treated neutrophils demonstrated 


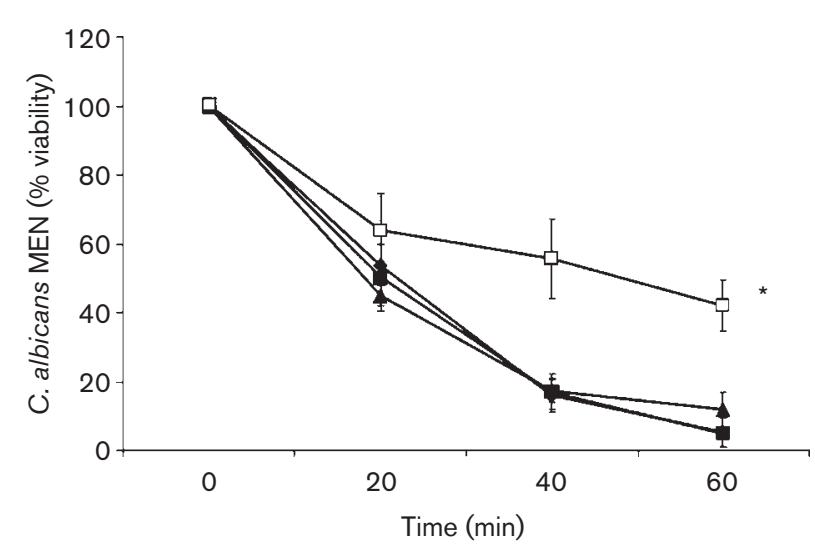

Fig. 1. Fumagillin inhibits the ability of neutrophils to kill yeast cells. Neutrophils $\left(1 \times 10^{7}\right)$ were pre-treated in the presence or absence of fumagillin $\left(2 \mu \mathrm{g}\right.$ or $\left.1 \mu \mathrm{g} \mathrm{ml}^{-1}\right)$, or in the presence of $0.2 \%(\mathrm{v} / \mathrm{v})$ methanol for $25 \mathrm{~min}$ at $37^{\circ} \mathrm{C}$. After washing, neutrophils were incubated with opsonized C. albicans $\left(5 \times 10^{6}\right)$ in a stirred, thermostatically controlled chamber. Aliquots were periodically removed and serially diluted in ice-cold MEM to quench phagocytosis. A diluted sample $(100 \mu \mathrm{l})$ was spread onto a YEPD agar plate and incubated at $30{ }^{\circ} \mathrm{C}$. Percentage reduction in viability was calculated based upon the viability at $t=0$. Methanol control; $\square, 2 \mu \mathrm{g}$ fumagillin $\mathrm{ml}^{-1} ; \mathbf{\Lambda}, 1 \mu \mathrm{g}$ fumagillin $\mathrm{ml}^{-1}$; $\boldsymbol{\square}$, PBS. The data are representative of three independent experiments. *Difference between $2 \mu \mathrm{g}$ fumagillin $\mathrm{ml}^{-1}$ treatment and control at $P<0.02$.

phagocytosis of conidia while $46.02 \pm 0.736 \%$ of the solvent (control)-treated cells showed phagocytosis $(P=0.015)$.

\section{Oxygen consumption}

The consumption of oxygen is essential for the microbicidal activity of neutrophils as oxygen is converted to

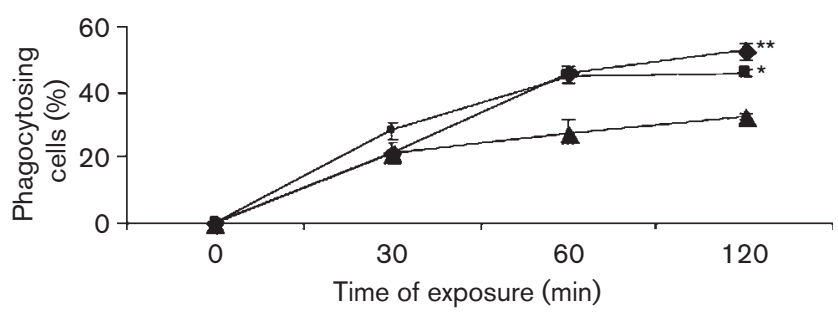

Fig. 2. Effect of fumagillin on in vitro phagocytosis by neutrophils. Neutrophils $\left(1 \times 10^{7}\right)$ were incubated in the presence of $2 \mu \mathrm{g}$ fumagillin $\mathrm{ml}^{-1}$ as described in Methods and incubated with serum-opsonized $A$. fumigatus conidia. Aliquots were removed periodically and examined by light microscopy to determine the level of phagocytosis. $\boldsymbol{\nabla}$, PBS; $\mathbf{\square}$, methanol control; $\boldsymbol{\Delta}, 2 \mu \mathrm{g}$ fumagillin. *Difference between methanol and fumagillin treatments at $P=0.015$. ${ }^{*}$ Difference between PBS and fumagillin treatments at $P=0.023$.
$\mathrm{O}_{2}^{-*}$ by the action of the NADPH oxidase complex in activated cells (Segal \& Jones, 1978). The oxygen consumption rate of PMA $\left(1 \mu \mathrm{g} \mathrm{m}{ }^{-1}\right)$-stimulated neutrophils $\left(1 \times 10^{7} \mathrm{ml}^{-1}\right)$ was measured using a Clark-type oxygen electrode as described in Methods. Control cells and those exposed to the solvent consumed $95.85 \pm 8.97 \mathrm{nmol}$ oxygen $\mathrm{ml}^{-1}$ within $10 \mathrm{~min}$ (Fig. 3). In contrast, neutrophils that had been exposed to $2 \mu \mathrm{g}$ fumagillin $\mathrm{ml}^{-1}$ for 25 min prior to PMA stimulation consumed 29.06 \pm $11.78 \mathrm{nmol}$ oxygen $\mathrm{ml}^{-1}$ over the same period, a reduction which is significant relative to the control at $P=0.017$.

\section{Modulatory effect of fumagillin on NADPH oxidase complex formation}

The NADPH oxidase complex consists of a number of proteins and a subset of these $\left(\mathrm{p} 40^{\text {phox }}, \mathrm{p} 47^{\text {phox }}, \mathrm{p} 67^{\text {phox }}\right.$ and $\mathrm{Rac}$ ) is located in the cytosol in unstimulated neutrophils but translocates to the membrane to form a functional complex in stimulated cells (Fuchs et al., 1995, 1996). The membrane fractions of fumagillin-treated and control neutrophils were isolated, resolved by 1-D SDSPAGE, blotted and probed with anti-p4 $7^{\text {phox }}$ antibody as described in Methods. Untreated neutrophils showed significantly less $\mathrm{p} 47^{\text {phox }}$ in the membrane fraction compared to PMA-stimulated cells $(P=0.011)$. The results demonstrated (Fig. 4) a large amount of $\mathrm{p} 47^{\text {phox }}$ in the membrane fraction of PMA-treated cells and in those which had been exposed to the solvent prior to PMA stimulation $(P=0.022)$. Those cells that had been exposed to $2 \mu \mathrm{g}$ fumagillin $\mathrm{ml}^{-1}$ showed a level of $\mathrm{p} 47^{\text {phox }}$ in the membrane fraction that was significantly lower $(P=0.026)$ than that in PMA-stimulated cells. The translocation event

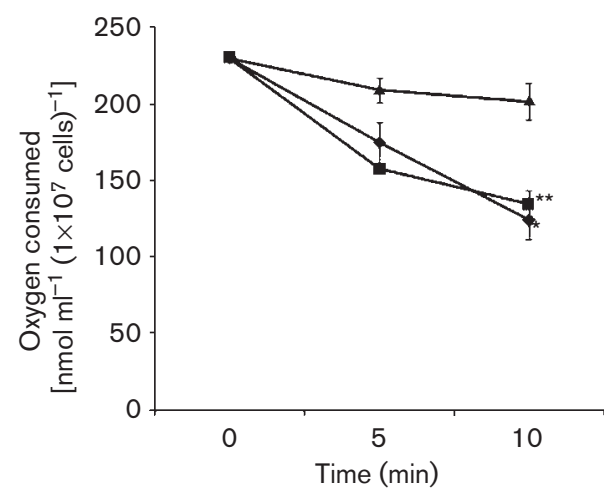

Fig. 3. Fumagillin inhibits the ability of neutrophils to consume oxygen. Neutrophils $\left(1 \times 10^{7}\right)$ were incubated in the presence or absence of $2 \mu \mathrm{g}$ fumagillin $\mathrm{ml}^{-1}$, washed and stimulated with $1 \mu \mathrm{g}$ PMA $\mathrm{ml}^{-1}$. The rate of oxygen depletion in the chamber was monitored over a $10 \mathrm{~min}$ period. Cells which had been pre-treated with fumagillin $(\mathbf{A})$ showed reduced ability to consume oxygen relative to PBS $(\boldsymbol{\Delta})\left({ }^{\star} P=0.032\right)$ and methanol $(\boldsymbol{\square})\left({ }^{\star \star} P=0.017\right)$ controls. The data presented are representative of four independent experiments. 

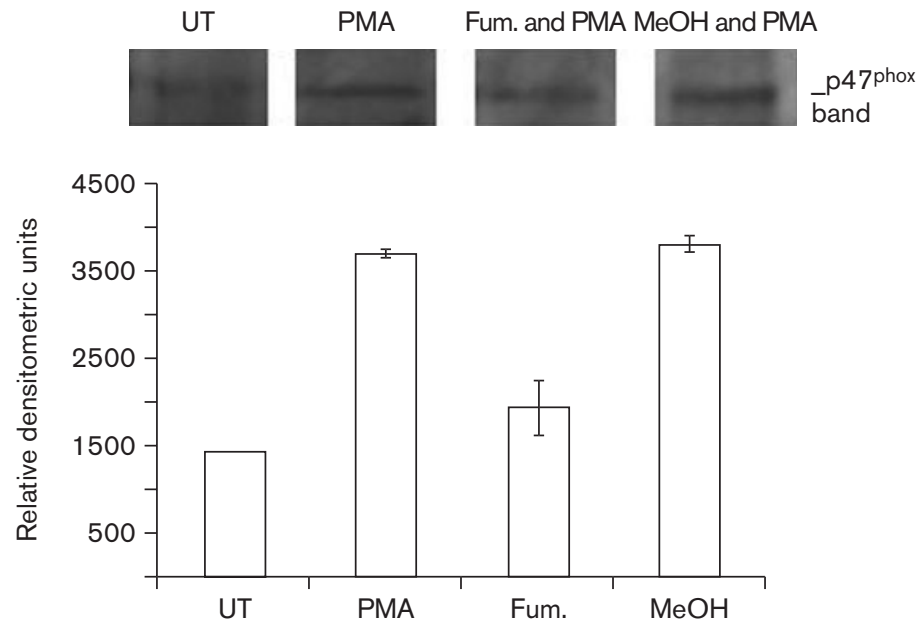

Fig. 4. Fumagillin inhibits the translocation of $\mathrm{p} 47^{\text {phox }}$ from the cytosol to the membrane. Neutrophils $\left(1 \times 10^{8}\right)$ were incubated in the presence or absence of $2 \mu \mathrm{g}$ fumagillin $\mathrm{ml}^{-1}$ and fractionated as described in Methods. The cytosolic and membrane components were subjected to electrophoresis and immunoblotting. Densitometry was used to quantify the relative band intensity of the reactive membrane-bound $\mathrm{p} 47^{\text {phox }}$ band. Membrane-bound p4 $7^{\text {phox }}$ was found to be reduced relative to PMA alone $(P=0.022)$, and $0.2 \%$ methanol incubation with PMA stimulation $(P<0.05)$. The data are representative of results obtained from three independent experiments. UT, Untreated cells. was also visualized by immunofluorescence microscopy using anti-p $47^{\text {phox }}$ antibody and a fluorescently labelled secondary antibody as described in Methods. The fluorescence in unstimulated cells was widely distributed throughout the cytoplasm (Fig. 5). In cells that were PMA-stimulated, the fluorescence was located in a zone around the cell's inner perimeter with a small amount of fluorescence remaining within the cytoplasm. Cells that had been exposed to fumagillin prior to PMA stimulation showed some concentration of fluorescence around the cell perimeter but also retained fluorescence within the cytoplasm. These results indicate that cells exposed to fumagillin showed reduced levels of translocation of $\mathrm{p} 47^{\text {phox }}$ to the membrane fraction of neutrophils and this could hinder the formation of an active NADPH oxidase complex in cells.

\section{Fumagillin inhibits degranulation of stimulated neutrophils}

The production of superoxide by PMA-stimulated neutrophils is associated with degranulation and the release of proteolytic enzymes into the phagocytic vacuole and around the cell perimeter (Standish \& Weiser, 2009).
Degranulation was measured by stimulating neutrophils with PMA in a stirred, thermally controlled chamber for $6 \mathrm{~min}$ and centrifuging the cell pellet at $800 \mathrm{~g}$. The supernatants from cells were resolved by SDS-PAGE, blotted and probed with anti-human MPO antibody. The results demonstrate (Fig. 6) that the amount of MPO released by neutrophils that were previously exposed to fumagillin was significantly reduced compared to that released by control cells $(P=0.035)$. The peroxidation activity of MPO from these supernatants was assessed as described in Methods. The results (Fig. 7) indicate a significant increase in peroxidation activity where PMA stimulation was employed. However, there was a significant decrease in the level of peroxidation activity evident when neutrophils were pre-treated with fumagillin and subsequently PMA-stimulated, relative to the PMA only and solvent control $(P=0.019$ and 0.012 , respectively). These results indicate that fumagillin reduced neutrophil degranulation but did not completely block the process.

\section{Fumagillin retards F-actin reassembly}

Actin in unstimulated neutrophils exists in the G form but upon stimulation it is converted to the $\mathrm{F}$ form in order for

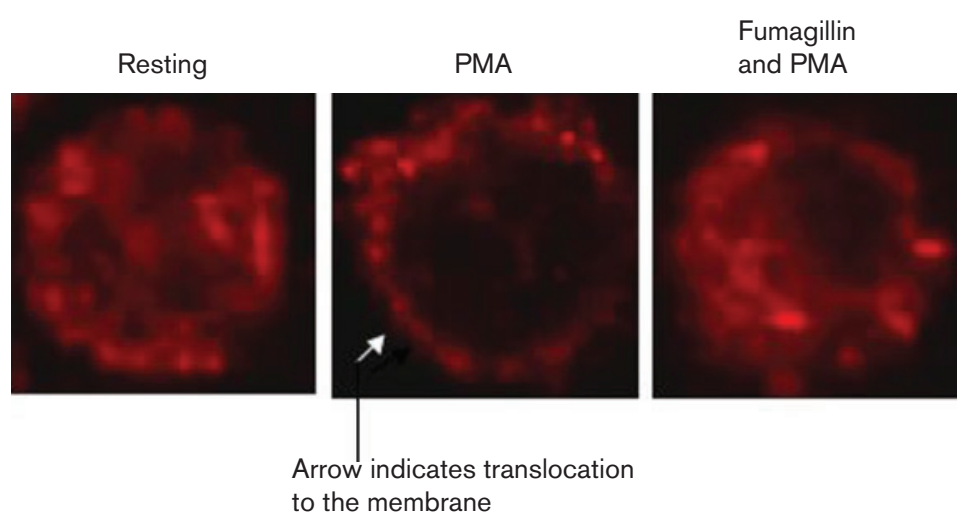

Fig. 5. Visualization of $\mathrm{p} 47^{\text {phox }}$ in neutrophils. Neutrophils were incubated in the presence of $2 \mu \mathrm{g}$ fumagillin $\mathrm{ml}^{-1}$ for $25 \mathrm{~min}$, washed, PMAstimulated, fixed and permeabilized as described in Methods. Untreated cells showed a wide dispersal of $\mathrm{p} 47^{\text {phox }}$ compared to PMAstimulated cells, which showed a high level of translocation to the membrane. Neutrophils which had been incubated with fumagillin showed some translocation to the membrane but retained most $\mathrm{p} 47^{\text {phox }}$ in the cytosol. 

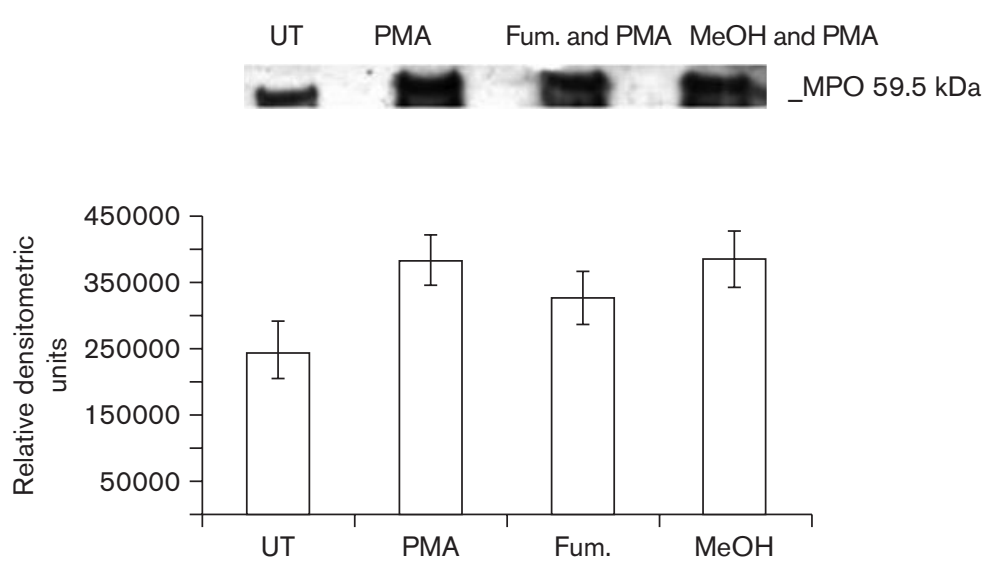

Fig. 6. Fumagillin inhibits neutrophil degranulation. Neutrophils $\left(5 \times 10^{7}\right)$ were incubated in the presence of $2 \mu \mathrm{g}$ fumagillin $\mathrm{ml}^{-1}$ for $25 \mathrm{~min}$ and placed in a stirred chamber at $37^{\circ} \mathrm{C}$. Six minutes following PMA stimulation the contents of the chamber were centrifuged at $800 \mathrm{~g}$ for $5 \mathrm{~min}$ and the supernatant was prepared for electrophoresis and immunoblotting. Reactive bands were used to quantify the effect of fumagillin on degranulation using densitometry. Neutrophils which had been exposed to fumagillin and stimulated with $1 \mu \mathrm{g}$ PMA ml ${ }^{-1}$ showed a reduction in the level of degranulation of MPO relative to untreated cells $(P<0.001)$ and the solvent/ PMA cells $(P<0.035)$. Data presented here are representative of the results of five independent experiments. UT, Untreated cells. phagocytosis, cytosolic protein translocation and degranulation to occur (Comera et al., 2007). Disruption of the conversion of actin from the $G$ to the $F$ form could be responsible for many of the effects observed here as the failure to produce sufficient F-actin would retard $\mathrm{p} 47^{\text {phox }}$ translocation, phagocytosis and degranulation.

In order to quantify the effect of fumagillin on F-actin assembly, neutrophils were exposed to the toxin as

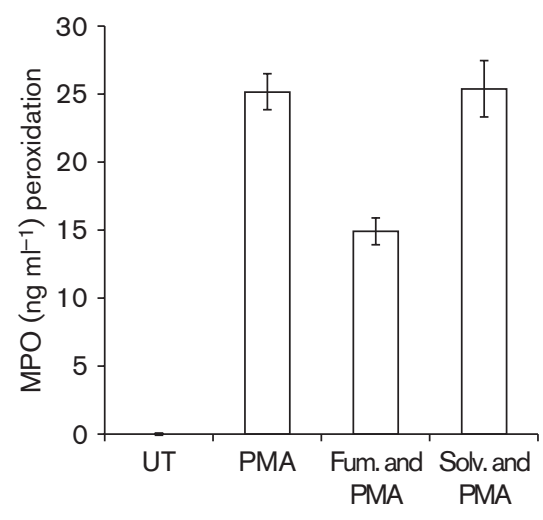

Fig. 7. Fumagillin inhibits the release of MPO. Neutrophils $\left(5 \times 10^{7}\right)$ were incubated in the presence of $2 \mu \mathrm{g}$ fumagillin $\mathrm{ml}^{-1}$ for $25 \mathrm{~min}$ and placed in a stirred chamber at $37{ }^{\circ} \mathrm{C}$. Six minutes following PMA stimulation the contents of the chamber were removed and centrifuged at $800 \mathrm{~g}$ for $5 \mathrm{~min}$. Protein $(10 \mu \mathrm{g})$ was incubated in the presence of $100 \mu \mathrm{l} 2 \times$ Amplex UltraRed working solution and the fluorescence intensity was read at excitation $530 \mathrm{~nm}$ and emission at $590 \mathrm{~nm}$. Difference in MPO peroxidation value of solvent/PMA-treated cells relative to fumagillin/PMA-treated cells at $P=\leqslant 0.019$. PMA-treated cells relative to solvent/PMA-treated cells $P=0.924$. UT, Untreated cells. described in Methods, and protein was extracted and separated by SDS-PAGE. Immunoblotting was employed in conjunction with densitometry of reactive bands specific for F-actin. The results (Fig. 8) show a significant decrease in the level of reactivity to F-actin specific antibody where neutrophils were exposed to fumagillin in conjunction with PMA stimulation compared to both PMA only and methanol in conjunction with PMA stimulation $(P \leqslant 0.05)$.

Untreated neutrophils and those pre-exposed to fumagillin prior to PMA stimulation were stained with rhodaminecoupled phalloidin, which is specific for F-actin (Comera et al., 2007), and cells were examined by immunofluorescence microscopy. The results (Fig. 9) indicate that in untreated cells, there was a small amount of fluorescence, whereas in PMA-treated cells, the level of fluorescence was greatly increased corresponding to the elevated levels of F-actin in these cells (Comera et al., 2007). The level of fluorescence in cells that had been pre-treated with fumagillin prior to PMA stimulation was greater than that in the untreated cells but less than that evident in PMAtreated cells. These results suggest that there is a lower level of F-actin in neutrophils that have been exposed to fumagillin.

\section{DISCUSSION}

A. fumigatus is a serious pathogen of immunocompromised patients, where it can induce a variety of potentially lifethreatening diseases (Brookman \& Denning, 2000). The production and secretion of hydrolytic enzymes and toxins by this fungus appears to play a key role in its ability to colonize host tissue and to neutralize the immune response (Rementeria et al., 2005). Fumagillin is produced by $A$. fumigatus but its role in facilitating colonization or suppressing immune function has not been fully elucidated. The aim of this work was to examine the interaction of this 


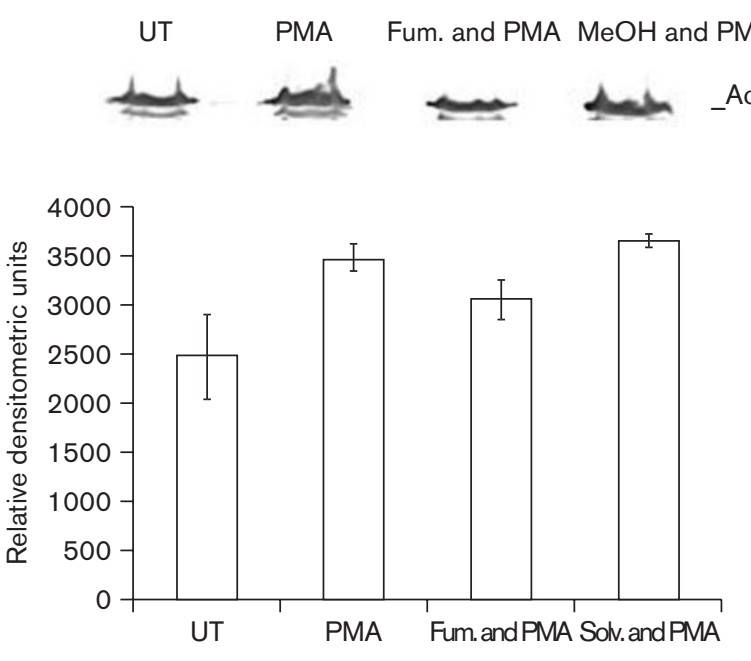

toxin with neutrophils, which are a key component of the innate immune response. Tsunawaki et al. (2004) previously examined the interaction of $A$. fumigatus toxins with neutrophils and demonstrated an inhibition of $\mathrm{p} 47^{\text {phox }}$ and $\mathrm{p} 67^{\text {phox }}$ translocation in gliotoxin-treated cells. In their work, the response of neutrophils to fumagillin at concentrations up to $125 \mu \mathrm{g} \mathrm{ml}{ }^{-1}$ was assessed and no significant change in neutrophil function (i.e. superoxide production) was noted at concentrations up to $64 \mu \mathrm{g} \mathrm{ml}^{-1}$. Interestingly, Amitani et al. (1995) demonstrated complete ciliostasis and epithelial cell disruption at $10 \mu \mathrm{g}$ fumagillin $\mathrm{ml}^{-1}$, and in the work presented here, neutrophils were exposed to a significantly lower concentration of fumagillin which did not affect the cell viability.
Fig. 8. Fumagillin inhibits the formation of Factin. Neutrophils $\left(5 \times 10^{7}\right)$ were incubated in the presence or absence of $2 \mu \mathrm{g}$ fumagillin $\mathrm{ml}^{-1}$, and stimulated with $1 \mu \mathrm{g}$ PMA $\mathrm{ml}^{-1}$, washed and resuspended in Breaks Buffer. Following lysis, cells were prepared for electrophoresis and immunoblotting as described in Methods. Untreated cells showed a background level of F-actin; however, following PMA stimulation or methanol incubation followed by PMA stimulation, cells showed increased F-actin reactivity. Cells which had been exposed to fumagillin prior to PMA stimulation showed a slight increase in F-actin relative to untreated cells $(P=0.05)$ but this reactivity was reduced compared to the positive controls (PMA and solvent/PMA) $(P<0.05)$. Densitometry was used to quantify band reactivity and the data presented here are representative of four independent experiments. UT, Untreated cells.
The results presented here indicate that exposure to $2 \mu \mathrm{g}$ fumagillin $\mathrm{ml}^{-1}$ retards the ability of human neutrophils to phagocytose and kill microbial cells. This appears to be mediated through an inhibition of $\mathrm{p} 47^{\text {phox }}$ translocation leading to a reduction in NADPH oxidase activity and to a diminution in neutrophil degranulation. Upon stimulation, neutrophils undergo a series of structural and functional rearrangements to enable the killing of ingested microbes, which is made possible by the conversion of G-actin to F-actin in order to facilitate the internal rearrangements (Misu et al., 2009). This work demonstrates that fumagillin may act by retarding the conversion of $\mathrm{G}$ to $\mathrm{F}$ actin and as a consequence this could hinder the other structural alterations associated with neutrophil activation.

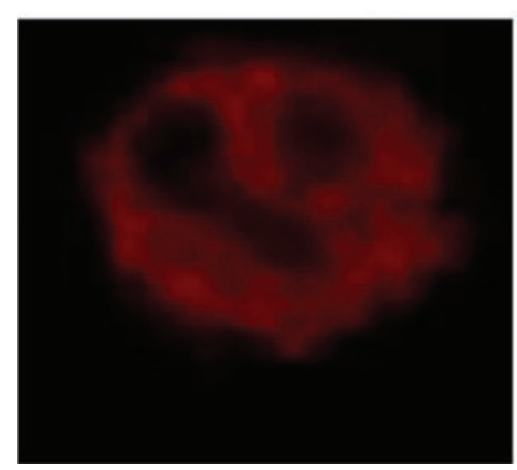

Resting cell

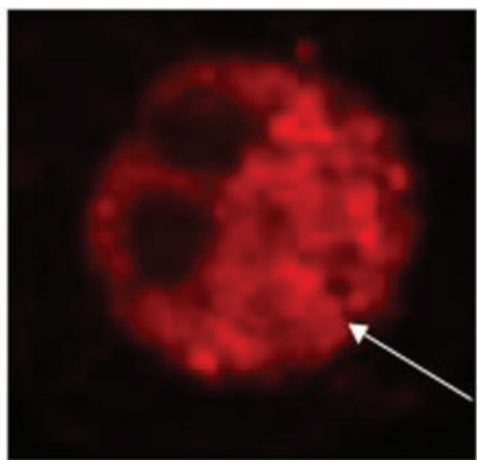

PMA-stimulated

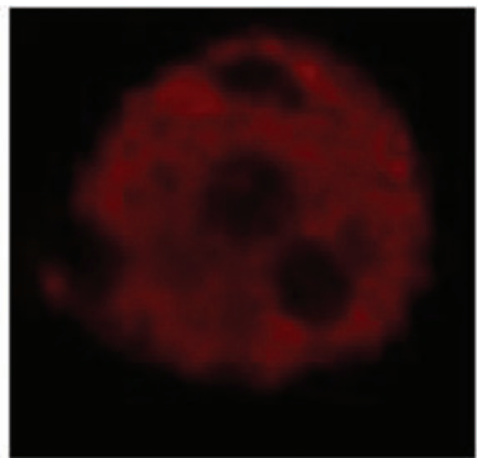

Fumagillin and PMA

Fig. 9. Visualization of rhodamine-coupled phalloidin staining of F-actin in neutrophils. Neutrophils were prepared as described in Methods and viewed by confocal microscopy. Untreated cells showed a low level of fluorescence relative to the increased fluorescence in PMA-treated cells, which was highly localized as indicated by the arrow. Fumagillin-treated cells which had been stimulated with PMA showed some reactivity but this was greatly reduced relative to the positive control. 
The translocation of the cytosolic components of the NADPH oxidase complex of neutrophils to the membrane component is essential for the activation of the NADPH oxidase complex (Reeves et al., 2002). This translocation event can be monitored by quantifying the amount of $\mathrm{p} 40^{\text {phox }}, \mathrm{p} 47^{\text {phox }}$ or $\mathrm{p} 67^{\text {phox }}$ located in the membrane fraction of stimulated neutrophils (Renwick et al., 2007). In stimulated cells, $\mathrm{p} 47^{\text {phox }}$ interacts with $\mathrm{p} 67^{\text {phox }}$ via the simultaneous binding of the $\mathrm{p} 67^{\text {phox }}$ C-terminal $\mathrm{SH} 3$ domain to both the proline-rich region of amino acid residues 360-369 and the C-terminally flanking region of $\mathrm{p} 47^{\mathrm{phox}}$. The coupled proteins then translocate as a single unit to the membrane, hence measuring the translocation of $\mathrm{p} 47^{\text {phox }}$ is a useful indicator of the translocation of the $\mathrm{p} 47^{\text {phox }}-\mathrm{p} 67^{\text {phox }}$ unit (Mizuki et al., 2005). Neutrophils exposed to fumagillin prior to PMA stimulation demonstrated a reduction in the translocation of $\mathrm{p} 47^{\text {phox }}$ by approximately $50 \%$ relative to the control (Fig. 4). This reduction in translocation is also evident by immunofluorescence, where high levels of translocation are evident in PMA-stimulated cells, which show a clearance of immunofluorescence from the centre of the cell, indicating that the $\mathrm{p} 47^{\mathrm{phox}}$ has migrated to the cell periphery (Fig. 5). Lower levels of $\mathrm{p} 47^{\text {phox }}$ translocation are apparent in those cells that had been pre-treated with fumagillin; however, some is evident, indicating a reduction in translocation rather than a complete inhibition of this process.

The process of degranulation results in the release of hydrolytic enzymes into the phagocytic vacuole and around the periphery of the cell and is an essential element of the neutrophil's ability to kill ingested micro-organisms (Spitznagel, 1990). PMA-stimulated cells underwent degranulation as evident by the large amount of MPO detected by Western blotting in the cell-free supernatant (Fig. 6). In contrast, neutrophils that had been pre-exposed to fumagillin showed levels of MPO release approximately $20 \%$ less than those of the PMA-treated cells. MPO peroxidation activity was also reduced in fumagillin/PMAtreated neutrophils relative to that evident in solvent/PMA or PMA-treated cells (Fig. 7).

The conversion of actin from the $G$ form to the $F$ form upon stimulation is central to the morphological and functional changes that occur within neutrophils and can be visualized by fluorescence of F-actin by rhodaminecoupled phalloidin. Previous research into mycotoxinmediated inhibition of neutrophil function has shown that gliotoxin induces a pronounced change in the neutrophil structure at the F-actin level with notable collapse around the nucleus, leading to cell shrinkage (Comera et al., 2007). The F-actin levels in fumagillin-treated neutrophils were significantly lower than those in PMA or solvent/PMAtreated cells at $P<0.05$ (Fig. 8). This is also apparent by immunofluorescence, where reduced fluorescence is evident in fumagillin-treated neutrophils, indicating lower amounts of F-actin in these cells (Fig. 9). Interestingly, it has been reported previously that the mycotoxin cytochalasin $\mathrm{D}(1 \mu \mathrm{M})$ induced significant rearrangements in $\mathrm{F}$ - actin of neutrophils and membrane retraction (Yürüker \& Niggli, 1992).

Previous work has indicated that growing colonies of $A$. fumigatus produce and secrete a range of metabolites that diffuse in advance of the growing hyphae and cause cell death and detachment (Daly \& Kavanagh, 2002). The ability of A. fumigatus to produce a variety of toxins may assist it in suppressing the local immune response (Rementeria et al., 2005) and enable growth over and through tissue (Amitani et al., 1995; Sutton et al., 1996). While great strides have been made in recent years in understanding the molecular biology of A. fumigatus (Brakhage \& Langfelder, 2002; Brookman \& Denning, 2000), much remains to be discovered about the interaction of the pathogen with the host and in particular how secreted enzymes and toxins (Rementeria et al., 2005) facilitate the growth of the fungus in the body and enable it to withstand the immune response. The work presented here demonstrates that concentrations of fumagillin that do not adversely affect viability can retard the activity of neutrophils and this has the potential to facilitate fungal persistence and colonization in vivo. The presence of fumagillin-producing strains of A. fumigatus in the lung may have a secondary effect in colonized patients. The ability of fumagillin to retard the activity of neutrophils may contribute to the increased levels of bacterial diseases evident in the lungs of cystic fibrosis patients and others with pre-existing pulmonary malfunction (Festini et al., 2006; Duff et al., 2006). It is possible that mycotoxins, such as fumagillin, may impair local immunity to such a degree as to facilitate the development of secondary infections without significantly improving the environment for the growth of A. fumigatus.

\section{ACKNOWLEDGEMENTS}

The authors have no conflicts of interest to disclose. This work was supported by funding from the Environmental Protection Agency of Ireland. The authors are grateful to Dr Ica Dix for assistance with confocal microscopy.

\section{REFERENCES}

Amitani, R., Murayama, T., Nawada, R., Lee, W. J., Niimi, A., Suzuki, K., Tanaka, E. \& Kuze, F. (1995). Aspergillus culture filtrates and sputum sols from patients with pulmonary aspergillosis cause damage to human respiratory ciliated epithelium in vitro. Eur Respir J 8, 16811687.

Babior, B. M., Kipnes, R. S. \& Curnette, J. T. (1973). Biological defence mechanisms: the production by leukocytes of superoxide, a potential bactericidal agent. J Clin Invest 52, 741-744.

Bellocchio, S., Moretti, S., Perrucio, K., Fallarino, F., Bozza, S., Montagnol, C., Mosci, P., Lipford, G. B., Pitzurra, L. \& Romaini, L. (2004). TLRs govern neutrophil activity in aspergillosis. J Immunol 173, 7406-7415.

Brakhage, A. A. \& Langfelder, K. (2002). Menacing mold: the molecular biology of Aspergillus fumigatus. Annu Rev Microbiol 56, 433-455. 
Brookman, J. L. \& Denning, D. W. (2000). Molecular genetics in Aspergillus fumigatus. Curr Opin Microbiol 3, 468-474.

Comera, C., Andre, K., Laffitte, K., Collet, X., Galtier, P. \& Maridonneau-Parini, I. (2007). Gliotoxin from Aspergillus fumigatus affects phagocytosis and organization of the actin cytoskeleton by distinct signaling pathways in human neutrophils. Microbes Infect $\mathbf{9}$, 47-54.

Curnutte, J. T., Kuver, R. \& Babior, B. M. (1987). Activation of the respiratory burst oxidase in a fully soluble system from human neutrophils. J Biol Chem 262, 6450-6452.

Daly, P. \& Kavanagh, K. (2002). Immobilization of Aspergillus fumigatus colonies in a soft agar matrix allows visualisation of A549 cell detachment and death. Med Mycol 40, 27-33.

de Mendez, I. \& Leto, T. (1995). Functional reconstitution of the phagocyte NADPH oxidase by transfection of its multiple components in a heterologous system. Blood 85, 1104.

Diesenhouse, M. C., Wilson, L. A., Corrent, G. F., Visvesvara, G. S., Grossniklaus, H. E. \& Bryan, R. T. (1993). Treatment of microsporidial keratoconjunctivitis with topical fumagillin. Am J Ophthalmol 115, 293-298.

Duff, C., Murphy, P. G., Callaghan, M. \& McClean, S. (2006). Differences in invasion and translocation of Burkholderia cepacia complex species in polarized lung epithelial cells in vitro. Microb Pathog 41, 183-192.

Eichner, R. D., Al Salami, M., Wood, P. R. \& Mullbacher, A. (1986). The effect of gliotoxin upon macrophage function. Int $J$ Immunopharmacol 8, 789-797.

Festini, F., Buzzetti, R., Bassi, C., Braggion, C., Salvatore, D., Tacetti, G. \& Mastella, G. (2006). Isolation measures for the prevention of infection with respiratory pathogens in cystic fibrosis: a systematic review. J Hosp Infect 64, 1-6.

Fuchs, A., Dagher, M. C. \& Vignais, P. V. (1995). Mapping the domains of interaction of $\mathrm{p} 40^{\text {phox }}$ and $\mathrm{p} 67^{\text {phox }}$ of the neutrophil oxidase complex using the two hybrid system. J Biol Chem 270, 56955697.

Fuchs, A., Dagher, M. C., Faure, J. \& Vignais, P. V. (1996). Topological organization of the cytosolic activating complex of the superoxide generating NADPH oxidase. Pinpointing the sites of interaction between $\mathrm{p} 47^{\text {phox }}, \mathrm{p} 67^{\text {phox }}$ and $\mathrm{p} 40^{\text {phox }}$ using the two-hybrid system. Biochim Biophys Acta 1312, 39-47.

Ingber, D., Fujita, T., Kishimoto, S., Sudo, K., Kanamaru, T., Brem, H. \& Folkman, J. (1990). Synthetic analogues of fumagillin that inhibit angiogenesis and suppress tumour growth. Nature 348, 555-557.

Malech, H. L. \& Nauseef, W. M. (1997). Primary inherited defects in neutrophil function: etiology and treatment. Semin Hematol 34, 279 290.

McCowen, M. C., Callender, M. E. \& Lawls, J. F. (1951). Fumagillin (H3), a new antibiotic with amebicidal properties. Science 113, 202203.

Misu, M., Furukawa, H., Kwon, H. J., Shikinaka, K., Kakugo, A., Satoh, T., Osada, Y. \& Gong, J. P. (2009). Photoinduced in-situ formation of various $\mathrm{F}$-actin assemblies with a photoresponsive polycation. J Biomed Mater Res A 89, 424-431.

Mitchell, C. G., Slight, J. \& Donaldson, K. (1997). Diffusable component from the spore surface of Aspergillus fumigatus which inhibits the macrophage oxidative burst is distinct from gliotoxin and other hyphal toxins. Thorax 52, 796-801.

Mizuki, K., Takeya, R., Kuribayashi, F., Nobuhisa, I., Kohda, D., Nunoi, H., Takeshige, K. \& Sumimoto, H. (2005). A region Cterminal to the proline rich core of $\mathrm{p} 47^{\text {phox }}$ regulates activation of the phagocyte NADPH oxidase by interacting with the C-terminal SH3 domain of p67 ${ }^{\text {phox }}$. Arch Biochem Biophys 444, 185-194.
Molina, J. M., Goguel, J., Sarfati, C., Michiels, J. F., Desportes-Livage, I., Balkan, S., Chastang, C., Cotte, L., Maslo, C. \& other authors (2000). Trial of oral fumagillin for the treatment of intestinal microsporidiosis in patients with HIV infection. AIDS 14, 1341-1348.

Orciuolo, E., Stanzani, M., Canestrano, M., Galimberti, S., Carulli, G., Lewis, R., Petrini, M. \& Komanduri, K. V. (2007). Effects of Aspergillus fumigatus gliotoxin and methylprednisolone on human neutrophils: implications for the pathogenesis of invasive aspergillosis. J Leukoc Biol 82, 839-848.

Reeves, E. P., Lu, H., Jacobs, H. L., Messina, C. G., Bolsover, S., Gabella, G., Potma, E. O., Warley, A., Roes, J. \& Segal, A. W. (2002). Killing activity of neutrophils is mediated through activation of proteases by K+ flux. Nature 416, 291-296.

Rementeria, A., López-Molina, N., Ludwig, A., Vivanco, A. B., Bikandi, J., Pontón, J. \& Garaizar, J. (2005). Genes and molecules involved in Aspergillus fumigatus virulence. Rev Iberoam Micol 22, 1-23.

Renwick, J., Reeves, E. P., Wientjes, F. B. \& Kavanagh, K. (2007). Translocation of proteins homologous to human neutrophil $\mathrm{p} 47^{\text {phox }}$ and $\mathrm{p} 67^{\mathrm{phox}}$ to the cell membrane in activated haemocytes of Galleria mellonella. Dev Comp Immunol 31, 347-359.

Segal, A. W. \& Coade, S. B. (1978). Kinetics of oxygen consumption by phagocytosing human neutrophils. Biochem Biophys Res Commun 84, 611-617.

Segal, A. W. \& Jones, O. T. G. (1978). Novel cytochrome b system in phagocytic vacuoles from human granulocytes. Nature 276, 515-517.

Spitznagel, J. K. (1990). Antibiotic proteins of human neutrophils. J Clin Invest 86, 1381-1386.

Standish, A. J. \& Weiser, J. N. (2009). Human neutrophils kill Streptococcus pneumoniae via serine proteases. J Immun 183, 26022609.

Stevanovic, J., Stanimirovic, Z., Radakovic, M. \& Stojic, V. (2008). In vitro evaluation of the clastogenicity of fumagillin. Environ $\mathrm{Mol}$ Mutagen 49, 594-601.

Sumimoto, H., Hata, K., Mizuki, K., Ito, T., Kage, Y., Sakaki, Y., Fukumaki, Y., Nakamura, M. \& Takeshige, K. (1996). Assembly and activation of the phagocyte NADPH oxidase. Specific interaction of the N-terminal Src homology 3 domain of $\mathrm{p} 47^{\text {phox }}$ with $\mathrm{p} 22^{\text {phox }}$ is required for activation of the NADPH oxidase. J Biol Chem 271, 22152-22158.

Sutton, P., Newcombe, N. R., Waring, P. \& Mullbacher, A. (1994). In vitro immunosuppressive activity of gliotoxin, a metabolite produced by human pathogenic fungi. Infect Immun 62, 1192-1198.

Sutton, P., Waring, P. \& Mulbacher, A. P. (1996). Exacerbation of invasive aspergillosis by the immunosuppressive fungal metabolite gliotoxin. Immunol Cell Biol 74, 318-322.

Tekaia, F. \& Latgé, J. P. (2005). Aspergillus fumigatus: saprophyte or pathogen. Curr Opin Microbiol 8, 385-392.

Thrasher, A. J., Keep, N. H., Wientjes, F. \& Segal, A. W. (1994). Chronic granulomatous disease. Biochim Biophys Acta 1227, 1-24.

Tsunawaki, S., Yoshida, L., Nishida, S., Kobayashi, T. \& Shimoyama, T. (2004). Fungal metabolite gliotoxin inhibits assembly of the human respiratory burst NADPH oxidase. Infect Immun 72, 3373-3382.

Wallach, T. M. \& Segal, A. W. (1996). Stoichiometry of the subunits of flavocytochrome b558 of the NADPH oxidase of phagocytes. Biochem J 320, 33-38.

Wientjes, F. B., Hsuan, J. J., Totty, N. F. \& Segal, A. W. (1993). p40 ${ }^{\text {phox }}$, a third activation complex of the NADPH oxidase to contain $\mathrm{SH} 3$ domains. Biochem J 296, 557-562.

Yürüker, B. \& Niggli, V. (1992). $\alpha$-Actinin and vinculin in human neutrophils: reorganization during adhesion and relation to the actin network. J Cell Sci 101, 403-414. 